\title{
FNAC AS A SIMPLE TOOL FOR THE DIAGNOSIS OF SUPERFICIAL LYMPHADENOPATHY- A STUDY IN AN INSTITUTE IN THE NORTH-EASTERN STATES OF INDIA
}

\author{
Kakchingtabam Urmila1, Sunita Haobam², Urmila Thiyam³
}

13rd Year Postgraduate Student, Department of Pathology, Jawaharlal Nehru Institute of Medical Sciences (JNIMS), Imphal, Manipur. ${ }^{2}$ Associate Professor, Department of Pathology, Jawaharlal Nehru Institute of Medical Sciences (JNIMS), Imphal, Manipur. ${ }^{3}$ Associate Professor, Department of Pathology, Jawaharlal Nehru Institute of Medical Sciences (JNIMS), Imphal, Manipur.

\section{ABSTRACT}

\section{BACKGROUND}

Enlargement of lymph nodes is called lymphadenopathy. Superficial lymphadenopathy is a common presentation in clinical practice. Fine needle aspiration cytology (FNAC) is simple, reliable and easily acceptable to the patients and has an important role in the diagnosis of superficial lymphadenopathies.

\section{MATERIALS AND METHODS}

The present study is a retrospective analysis of 378 cases of enlarged, superficial lymph nodes referred to the Department of Pathology, JNIMS (Manipur), for a period of four years i.e. January 2013 to December 2016. We aim to present the various cytomorphologic diagnosis of these cases.

\section{RESULTS}

Our study observed that non-specific reactive lymphadenopathy was the most common pathology and was seen in 176 cases (46.56\%), most common in the age group of 11 to 20 years and among females the occurrence of tubercular lymphadenopathy was also quite high and was seen in 122 cases (32\%) constituting the second most common presentation. Acute suppurative lymphadenitis made up 47 cases (12.43\%). Both tubercular and suppurative lymphadenopathies were seen most commonly in the age group of 21 to 30 years and also common among females. Metastatic lymph nodes were found in the age group above 60 years and constituted 19 cases (5.02\%) and was seen more commonly among the male patients. Malignant lymphomas were seen commonly in the age group of 50 to 60 years, non-Hodgkin's lymphoma made up 11 cases (2.9\%) with female preponderance, while Hodgkin's lymphoma was seen in only 3 cases $(0.79 \%)$ and more common among males. We also observed that in all these cases cervical lymphadenopathy was the most common presentation constituting 292 cases (77.24\%).

\section{CONCLUSION}

Superficial lymphadenopathy is a common clinical presentation. The underlying cause can vary from a curable inflammatory lesion to a fatal malignant lesion. In this study, we present the role of FNAC in the cytomorphologic diagnosis of various forms of superficial lymphadenopathies.

\section{KEYWORDS}

FNAC: Fine Needle Aspiration Cytology; Lymphadenopathy; Cytomorphology.

HOW TO CITE THIS ARTICLE: Urmila K, Haobam S, Thiyam U. FNAC as a simple tool for the diagnosis of superficial lymphadenopathy- a study in an institute in the North-Eastern States of India. J. Evolution Med. Dent. Sci. 2018;7(11):1328-1332, DOI: $10.14260 /$ jemds/2018/302

\section{BACKGROUND}

Enlarged lymph nodes are referred to as lymphadenopathy.(1) It was a common clinical finding among patients attending the outpatient department. The cytomorphological patterns of the lymph nodes would vary, depending on the causative underlying disease and the response of the organ which might range from a simple curable benign lesion to a fatal malignant pathology.(2)

Fine needle aspiration cytology is a simple, reliable, inexpensive and easily acceptable diagnostic tool for superficial lymphadenopathies, $(3,4)$ even though limitations

'Financial or Other Competing Interest': None.

Submission 28-01-2018, Peer Review 21-02-2018,

Acceptance 27-02-2018, Published 12-03-2018.

Corresponding Author:

Urmila Thiyam,

C/o. Dr. Salam Nongthon,

Singjamei Mayengbam Leikai,

Near NRL Oil Pump and SDO Club,

Imphal West-795008, Manipur.

E-mail: urmilath2014@gmail.com

DOI: $10.14260 /$ jemds $/ 2018 / 302$

and pitfalls do exist for this method like any other investigative procedure.

The present study is an attempt to show the use of FNAC in the various cytomorphological diagnosis of enlarged lymph nodes in patients presenting with superficial lymphadenopathies, referred to the Department of Pathology, Jawaharlal Nehru Institute of Medical Sciences (JNIMS) Imphal, Manipur. We present our experience in 378 cases of lymphadenopathies we came across during a period of 4 years, i.e. January 2013 to December 2016. Our objective is to list the cytomorphological profile of superficial lymphadenopathy.

\section{MATERIALS AND METHODS}

The present study is a retrospective analysis of lymph node FNAC. We collected the data from the records of Department of Pathology, JNIMS. We aspirated on 378 cases of enlarged superficial lymph nodes after taking an informed consent following a short clinical history and thorough clinical examination along with evaluation of other related investigation findings. Aspirations were taken from three anatomical sites (cervical, axillary and inguinal lymph nodes). 
FNAC was done by a cytopathologist using a $22-24 \mathrm{G}$ needle attached to a $10 \mathrm{~mL}$ syringe and Franzen handle. Aspiration was done from the largest lymph node or from multiple sites if the lymph node was very large or if many sites were involved, usually giving $2-3$ passes. The aspirate was then smeared on a minimum of 5 slides, four were air dried and one was fixed in $95 \%$ ethanol. Three air dried smears were routinely stained with Giemsa stain. Papanicolaou (PAP) stain was done from the alcohol fixed smear as and when required. Ziehl-Neelsen stain for acid-fast bacilli (AFB) was also done in cases of suspected tubercular lymphadenitis from the remaining air-dried smear. A cytopathologist studied all the stained smears and an appropriate diagnosis was given depending on the cytomorphological features and in correlation with the clinical findings. Analysis of the collected data was then carried out. The cytological diagnosis could be classified into the following main groups. Non-specific reactive lymphadenitis, tuberculous lymphadenitis (TB), acute suppurative lymphadenitis, metastatic lymph nodes, non-Hodgkin's lymphoma (NHL) and Hodgkin's lymphoma (HL). Smears that had scanty lymphoid elements, poor cell preservation, too much blood and necrosis were discarded as unsatisfactory smears and a repeat aspiration was carried out.

An aspirate showing evidence of polymorphic population of lymphoid cells along with histiocytes and tingible body macrophages and plasma cells, (eosinophils, polymorphs, variable) were taken as suggestive of non-specific reactive lymphadenitis.(5) In such a similar picture, if there were prominent neutrophilic infiltration with plenty of pus cells and degenerated cellular debris, having a purulent character, a diagnosis suggesting acute suppurative lymphadenitis(5) was given when negative for AFB.

When the smears showed increased cellularity with cells foreign to the lymph nodes with normal or reactive lymphoid cells in the background, a diagnosis of metastatic lymph node ${ }^{(5)}$ was given.

Aspirate smears which showed a polymorphous population of neutrophils, plasma cells, eosinophils along with the characteristic Reed-Sternberg cells were given a diagnosis of Hodgkin's lymphoma (HL). When the smears showed a monotonous population of lymphoid cells with mainly rounded nuclei slightly larger than those of normal small lymphocytes and many mitotic figures were taken as suggestive of non-Hodgkin's lymphoma (NHL).(5)

\section{RESULTS}

A total number of 378 cases of lymphadenopathies with clinical diagnosis were aspirated during a period of 4 years. On analysis of the data we observed that 176 cases (46.56\%) were given a diagnosis of non-specific reactive lymphadenitis and was the most common presentation (Table 1). Tubercular lymphadenitis comprised 122 cases (32.27\%) constituting the second most common presentation. In our study, we came across four categories of tubercular lymphadenitis: 1. Granulomas without necrosis or AFB; 2. Caseation necrosis with positive for AFB; 3. Caseation necrosis with neutrophilic infiltration with or without granuloma, even though AFB were absent; 4. Granuloma with caseation necrosis (Table 2). A number of conditions like cat scratch disease, sarcoidosis etc. also showed granuloma(6); however, in a place where tuberculosis was common and other granulomatous diseases were rare presence of granuloma in FNAC smears was highly suggestive of tuberculosis.(7) Acute suppurative lymphadenitis was seen in 47 cases $(12.43 \%)$ (Table 1$)$. Metastatic carcinoma was seen in 19 cases $(5.02 \%)$ with a male preponderance and common in the age group above 60 years (Table 4). Non-Hodgkin's lymphoma and Hodgkin's lymphoma made up 11 (2.9\%) and 3 cases $(0.79 \%)$ respectively. In our study, Hodgkin's lymphoma was seen commonly in the age group ranging from 50 to 60 years, while NHL was seen more often in the age group of above 60 years. Our study showed an overall female preponderance with a male-to-female ratio of 134: 244 (0.54\%) (Table 4).

\begin{tabular}{|c|c|c|}
\hline Cytologic Diagnosis & $\begin{array}{c}\text { No. of } \\
\text { Cases }\end{array}$ & $\begin{array}{c}\text { \% } \\
\text { Age }\end{array}$ \\
\hline Non-specific reactive lymphadenitis & 176 & $46.56 \%$ \\
\hline Tubercular lymphadenitis & 122 & $32.27 \%$ \\
\hline Acute suppurative lesion & 47 & $12.43 \%$ \\
\hline Metastatic carcinoma & 19 & $5.02 \%$ \\
\hline Non-Hodgkin's lymphoma & 11 & $2.9 \%$ \\
\hline Hodgkin's lymphoma & 3 & $0.79 \%$ \\
\hline Grand Total & \multicolumn{2}{|c|}{$\mathbf{3 7 8}$} \\
\hline Table 1. Cytologic Diagnosis of 378 Cases of \\
Lymphadenopathy \\
\hline
\end{tabular}

\begin{tabular}{|c|c|c|}
\hline Cytomorphology & Number of Cases & Percentage \\
\hline $\begin{array}{c}\text { Chronic granulomatous } \\
\text { lymphadenitis }\end{array}$ & 43 & $11.38 \%$ \\
\hline $\begin{array}{c}\text { Caseating tubercular } \\
\text { lymphadenitis }\end{array}$ & 28 & $7.41 \%$ \\
\hline $\begin{array}{c}\text { Suppurative tubercular } \\
\text { lymphadenitis }\end{array}$ & 5 & $1.3 \%$ \\
\hline $\begin{array}{c}\text { Caseating granulomatous } \\
\text { lymphadenitis }\end{array}$ & 46 & $12.16 \%$ \\
\hline Total & $\mathbf{1 2 2}$ & $\mathbf{3 2 . 2 7} \%$ \\
\hline Table 2. Patterns of Tubercular Lymphadenitis \\
\hline
\end{tabular}

\begin{tabular}{|c|c|c|c|c|c|c|}
\hline \multicolumn{7}{|c|}{ Lymph Node Groups involved in Various Types of } \\
Lymphadenopathy \\
\hline Site & Reactive & Tubercular & Metastatic & \multicolumn{2}{|c|}{$\begin{array}{c}\text { Malignant } \\
\text { Lymphoma }\end{array}$} & $\begin{array}{c}\text { Acute } \\
\text { Suppurative } \\
\text { Lymph- } \\
\text { adenitis }\end{array}$ \\
\hline Cervical & 142 & 96 & 15 & 3 & 8 & 28 \\
\hline Axillary & 20 & 18 & 3 & 0 & 1 & 3 \\
\hline Inguinal & 14 & 8 & 1 & 0 & 2 & 6 \\
\hline Total & $\mathbf{1 7 6}$ & $\mathbf{1 2 2}$ & $\mathbf{1 9}$ & $\mathbf{3 1 1}$ & $\mathbf{4 7}$ \\
\hline Table 3. Sites of Lymph Node Involvement (n= 378) \\
\hline
\end{tabular}

\begin{tabular}{|c|c|c|c|c|c|c|c|c|c|c|c|c|}
\hline \multirow{3}{*}{\begin{tabular}{|c|} 
Age \\
Group \\
(Years)
\end{tabular}} & \multirow{2}{*}{\multicolumn{2}{|c|}{ Reactive }} & \multirow{2}{*}{\multicolumn{2}{|c|}{\begin{tabular}{|c|} 
Acute \\
Suppurative
\end{tabular}}} & \multirow{2}{*}{\multicolumn{2}{|c|}{ Tubercular }} & \multirow{2}{*}{\multicolumn{2}{|c|}{ Metastati }} & \multicolumn{4}{|c|}{ Lymphoma } \\
\hline & & & & & & & & & $\mathrm{H}$ & & NH & \\
\hline & M & $\mathbf{F}$ & M & $\mathbf{F}$ & M & $\mathbf{F}$ & M & $\mathbf{F}$ & M & $\mathbf{F}$ & $\mathbf{M}$ & $\mathbf{F}$ \\
\hline $0-10$ & 11 & 18 & & 6 & - & & & 0 & 0 & 0 & \begin{tabular}{|l|l}
0 & 1 \\
\end{tabular} & 0 \\
\hline $11-20$ & 19 & 36 & 5 & 3 & 8 & 8 & 0 & 0 & 0 & 0 & 0 & 0 \\
\hline $21-30$ & 3 & 24 & 2 & 9 & 10 & 18 & 0 & 1 & 0 & 0 & 0 & 0 \\
\hline $31-40$ & 2 & 27 & 1 & 2 & 7 & 17 & 0 & 0 & 0 & 0 & 0 & 1 \\
\hline $41-50$ & 7 & 13 & 2 & 3 & 10 & 10 & 3 & 2 & 0 & 0 & 1 & 1 \\
\hline $51-60$ & 1 & 7 & 1 & 6 & 3 & 8 & 5 & 1 & 2 & 0 & 1 & 2 \\
\hline$>60$ & 3 & 5 & 2 & 1 & 8 & 3 & 4 & 3 & 1 & 0 & 2 & 3 \\
\hline Total & 46 & 130 & 17 & 30 & 51 & 71 & 12 & 7 & 3 & $\mathbf{0}$ & 4 & 7 \\
\hline
\end{tabular}




\begin{tabular}{|c|c|c|c|c|}
\hline $\begin{array}{c}\text { No. of } \\
\text { Cases }\end{array}$ & $\begin{array}{c}\text { Metastatic } \\
\text { Carcinoma Un- } \\
\text { differentiated }\end{array}$ & $\begin{array}{c}\text { Metastatic } \\
\text { Squamous } \\
\text { Cell } \\
\text { Carcinoma }\end{array}$ & $\begin{array}{c}\text { Metastatic } \\
\text { Small Cell } \\
\text { Carcinoma }\end{array}$ & $\begin{array}{c}\text { Metastatic } \\
\text { Adenocarcinoma }\end{array}$ \\
\hline 19 & $\begin{array}{c}3 \\
(15.79 \%)\end{array}$ & $\begin{array}{c}9 \\
(47.37 \%)\end{array}$ & $\begin{array}{c}1 \\
(5.26 \%)\end{array}$ & $\begin{array}{c}6 \\
(31.58 \%)\end{array}$ \\
\hline \multicolumn{4}{|c|}{ Table 5. Metastatic Carcinoma (19 Cases) } \\
\hline
\end{tabular}

The youngest patient was a boy of 1 year who presented with acute suppurative lymphadenitis and the oldest patient was a male patient of 82 years who presented with metastatic carcinoma. Cervical lymph nodes were involved in 292 cases $(77.24 \%)$ and was found to be the most commonly involved group in all types of lymphadenopathy (Table 3). Hodgkin's lymphoma showed $100 \%$ involvement of cervical lymph node. Axillary lymph nodes were involved in 55 cases (14.55\%), while inguinal lymph nodes were involved in only 31 cases $(8.2 \%)$ and was found to be the lymph node group least commonly involved (Table 3 ) and multiple lymph nodes were involved in 10 cases $(2.64 \%)$. The size of the lymph nodes varied from $0.5 \mathrm{~cm}$ to $4.5 \mathrm{~cm}$. The lymph node was discrete and freely mobile in reactive lymphadenitis, soft-tofirm, matted and usually multiple in tuberculosis, while they were firm-to-hard and fixed in majority of the metastatic lymph nodes. Maximum number of cases were recorded in the age group of 11 to 20 years constituting 80 cases $(21.16 \%)$. And least number of cases were seen in the age group above 60 years comprising 35 cases (9.25\%) (Table 4). Non-specific reactive lymphadenitis was most common in the age range of 11 - 20 years with a female preponderance showing a male-to-female ratio of (19: 36). Tuberculosis was found to be more common in the age group of 21 - 30 years and more common among females showing a male-to-female ratio of (10: 18).

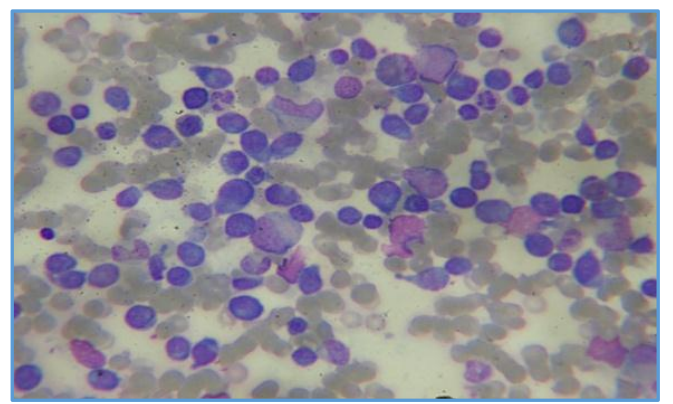

Photomicrograph 1. Photomicrograph of FNA Smear showing a Polymorphous Population of Lymphoid Cells in Non-Specific Reactive Lymphadenitis

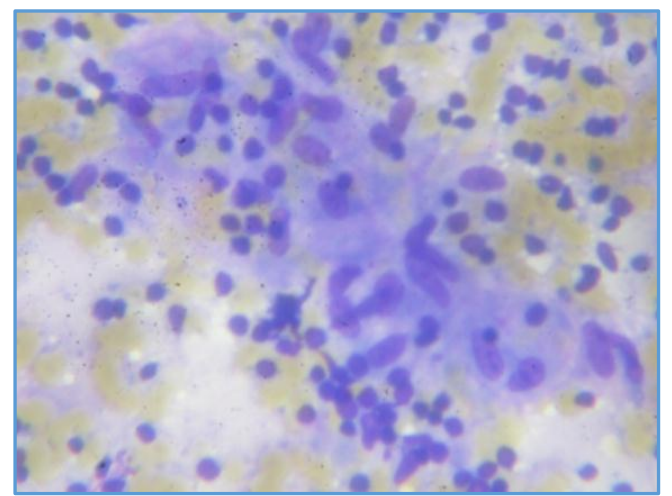

Photomicrograph 2. FNA Smear showing a Collection of Epithelioid Cells in Chronic Granulomatous Lymphadenitis

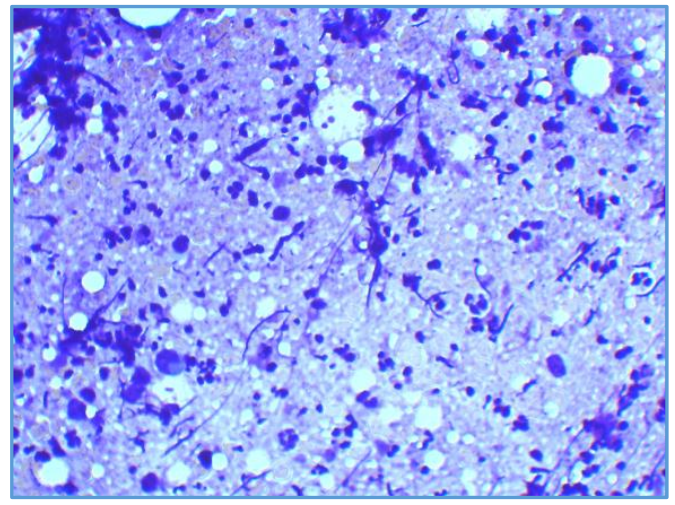

Photomicrograph 3. FNA Smear showing Acute Suppurative Lymphadenitis

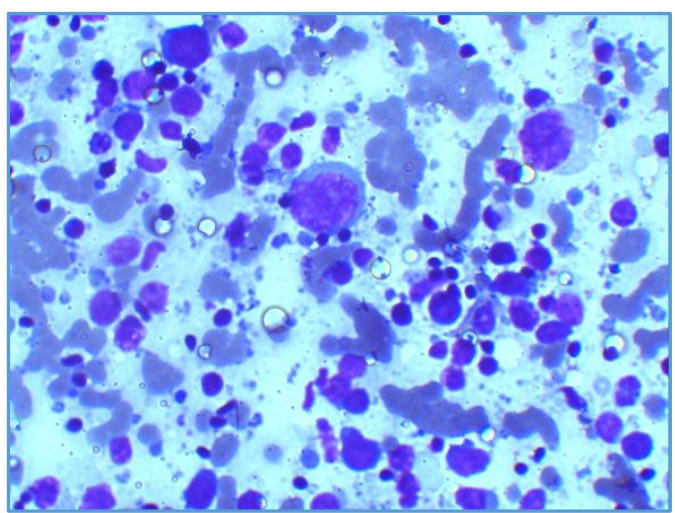

Photomicrograph 4. FNA Smear showing Reed-Sternberg Cell in Hodgkin's Lymphoma

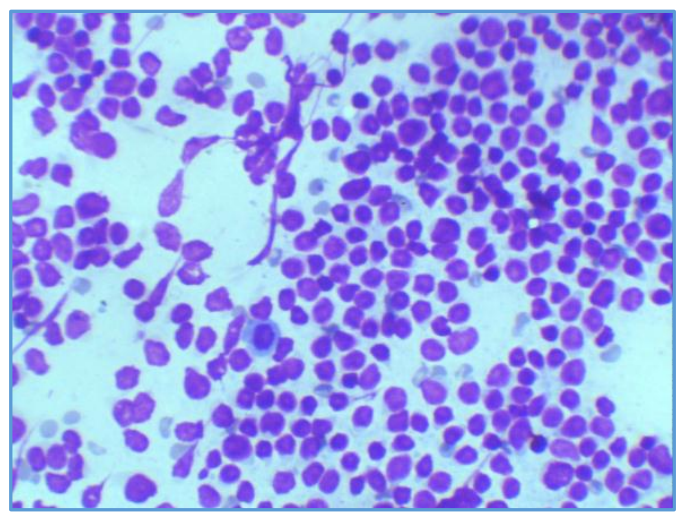

Photomicrograph 5. FNA Smear showing a Monotonous Population of Lymphoid Cells and Mitotic Figure in NonHodgkin's Lymphoma

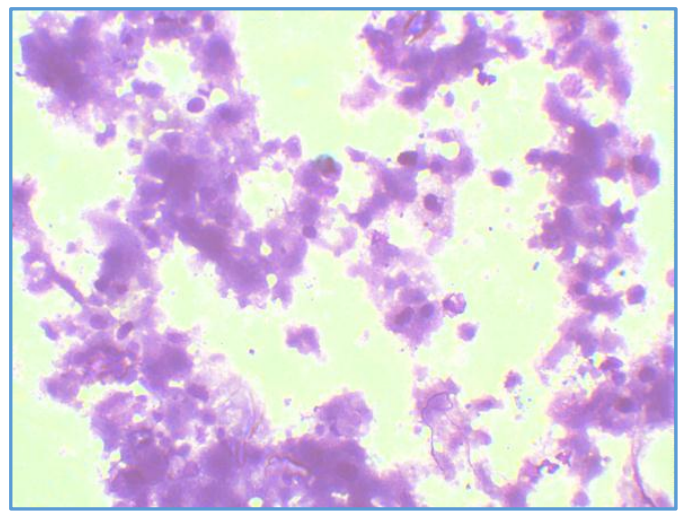

Photomicrograph 6. FNA Smear showing Caseation Necrosis in Caseating Lymphadenitis 


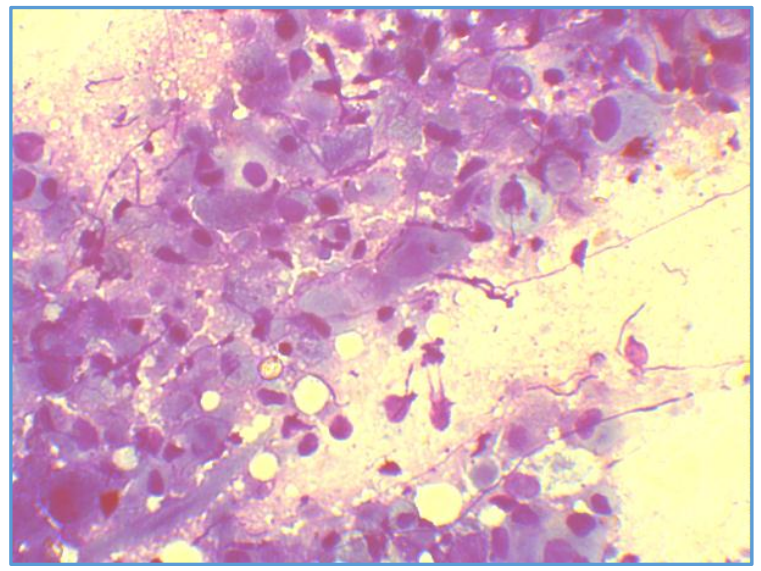

Photomicrograph 7. FNA Smear showing Metastatic Squamous Cell Carcinoma

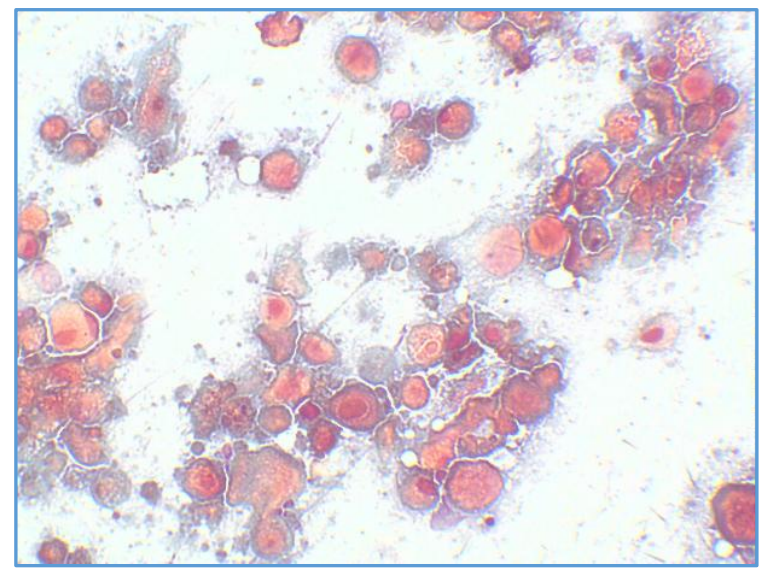

Photomicrograph 8. FNA Smear showing Metastatic Squamous Cell Carcinoma (Pap Stain)

\section{DISCUSSION}

In this area of north-eastern region (Manipur), where advanced and costly diagnostic facilities were not easily available to all groups of patients, FNAC formed an easy, inexpensive, reliable and readily acceptable diagnostic tool for superficial lymphadenopathies. In our study we presented the cytomorphologic diagnosis of 378 cases of lymphadenopathies over a period of 4 years, i.e. January 2013 to December 2016. The patterns of lesions included nonspecific reactive lymphadenopathy, tubercular lymphadenopathy, suppurative lymphadenopathy, metastatic lymph nodes, Hodgkin's and Non-Hodgkin's lymphoma. In this study, non-specific reactive lymphadenitis was found to be the most common presentation (46.56\%) and common in age group of 11 to 20 years with female preponderance M:F::19:36, which was in concordance with findings of GD Forae and CC Nwafor,(8) who also showed the highest incidence of non-specific reactive lymphadenitis constituting $36.3 \%$ and a high female involvement, even though the M:F::27:26. Tubercular lymphadenopathy was also found to show a high incidence in this part of the country presenting 122 cases $(32.27 \%)$. It turned out to be the second most common cause of enlarged lymph nodes, which was slightly deviated from the findings of other studies $(4,9,10)$ who showed that tuberculous lymphadenopathy as the most common presentation in India, giving a total of $56.92 \%, 38.52 \%$ and $37.8 \%$ respectively. These findings were very different from the findings in western countries, where there was a very low prevalence of tuberculosis $1.6 \%$.(11) We also observed that in tuberculosis cervical lymph nodes were most frequently involved, even though axillary and inguinal groups could also be involved. Maximum cases were seen in the age group of 21 to 30 again with a female preponderance (M:F::51:71). A female preponderance of tubercular lymphadenitis had also been observed by other studies.(3,4) The overall low standard of living of females with frequent childbirth in this area and the associated poor nutrition might be the cause.

The highest incidence of metastatic lymph node was seen in the elderly age group of above 60 years with a male preponderance M:F::4:3 and the maximum deposits were of squamous cell carcinoma 9 cases $(47.3 \%)$, which was in concordance with the findings of $(4,9)$ who also showed squamous cell carcinoma to be the predominant deposit comprising of $42.55 \%$ and $92.68 \%$ respectively. This might be because of the lifestyle and food habits of the patients. Malignant lymphoma was seen in $2.91 \%$, which was comparable with the findings in other studies(4) where it formed $2.79 \%$. Hodgkin's lymphoma was seen in only 3 cases (0.79\%).

Lymph nodes of the neck were most commonly involved, followed by axillary group of lymph nodes. Similar findings were also observed by other studies.(12)

\section{CONCLUSION}

Superficial lymphadenopathy is a common clinical presentation. FNAC has an important role in the diagnosis of superficial lymphadenopathies. It is easy, safe, rapid, reliable and readily acceptable to the patients. In our study, we presented the role of FNAC in the cytomorphological diagnosis of various forms of superficial lymphadenopathies ranging from benign inflammatory lesions to fatal malignant lesions.

\section{REFERENCES}

[1] Darnal HK, Karim N, Kamini K, et al. The profiile of lymphadenopathy in adults and children. Med J Malasia 2005;60:590-8.

[2] Pandit AA, Candes FP, Khubchandini SR. Fine needle cytology of lymph nodes. J Postgrad Med 1987;33(3):134-6.

[3] Pavithra P, Geetha JP. Role of fine needle aspiration cytology in the evaluation of the spectrum of lymph nodes lesions. Int J Pharm Bio Sci 2014;5(4):377-84.

[4] Sharma P, Rana S, Gill MK, et al. Spectrum of lymph node lesions on cytology in rural Haryana: a retrospective analysis. Int $\mathrm{J}$ Res Med Sci 2015;3(5):1125-30.

[5] Orell SR, Strerrett GF, Max NI, et al. Lymph nodes. Manual and Atlas of fine needle aspiration cytology. $3^{\text {rd }}$ edn. London: Churchill Livingstone 1999: p. 73-108.

[6] Finer M, Perchick A, Barstein DE. Fine needle aspiration biopsy diagnosis of syndrome. Tuberculous lymphadenitis in patients with or without the acquired immune deficiency. Acta Cytol 1991;35(3):325-32.

[7] Lau SK, Wei WI, Hsu C, et al. Efficacy of fine needle aspiration cytology in the diagnosis of tuberculous cervical lymphadenopathy. J Laryngol Otol 1990;104(1):24-7. 
[8] Forae GD, Nwafor CC. Spectrum of cytological findings in patients with superficial lymphadenopathy: an experimental status in a Nigerian teaching hospital. JBMR (Journal of Medical and Biomedical Research) 2013;12(1):30-6.

[9] Kochhar AK, Puri PL, Kochhar S. Role of fine needle aspiration cytology in the assessment of cervical lymphadenopathy. Int J Med Res Rev 2016;4(6):87680.
[10] Patra AK, Nanda BK, Mohapatra BK, et al. Diagnosis of lymphadenopathy by fine needle aspiration cytology. Indian J Pathol Microbiol 1983;26(4):273-8.

[11] Kline TS, Khannan V, Kine IK. Lymphadenopathy and aspiration biopsy cytology. Review of 376 superficial lymph nodes. Cancer 1984;54(6):1076-81.

[12] Gayathri MN, Chaurasia S, Bharathi M, et al. Pattern of lymphadenopathy in fine needle aspiration cytology: a retrospective study. Int J Res Med Sci 2015;3(6):14169. 